\title{
Cybernotary as Support for Cybersecurity and Resilience
}

\author{
Finna Nazran ${ }^{1}$, Tan Kamello ${ }^{2}$, Hasim Purba ${ }^{3}$, OK. Saidin ${ }^{4}$ \\ \{finanazran@gmail.com ${ }^{1}$, tankamelo77@gmail.com² , hasim.purba@usu.ac.id ${ }^{3}$, saidin@ usu.ac.id ${ }^{4}$ \}
}

Universitas Sumatera Utara, Indonesia ${ }^{1,2,3,4}$

\begin{abstract}
Cybernotary is intended to facilitate and accelerate the process of creating authentic deeds, including complying with all actions, agreements, or provisions required by law and ensuring all requested statements from interested parties are stated in the authentic deed. Strong, professional, and reliable institutional support is needed to ensure that the objectives of cyber defense can be achieved. This research analyzes the impact of the cybernotary in supporting Indonesia's cyber defense and security. This research implements a normative juridical method using a conceptual approach. The data sources are primary, secondary, and tertiary legal materials. The results of this study indicate that cybernotaries facilitate and accelerate the process of creating authentic deeds, including complying with all actions, agreements, or provisions required by law and ensuring all requested statements from interested parties are stated in the authentic deed. To increase the competence of notaries on information technology systems, it is necessary to have appropriate regulations with the agreement of all related parties. In addition, these regulations must be registered at the national level, not sectoral. Hopefully, the enforcement of government authority in cybersecurity and resilience respects human rights, as the concept of a cybernotary is always associated with long-distance services.
\end{abstract}

Keywords: Cybernotary, Security, Resilience, Cyber

\section{Introduction}

Globalization has awakened the age-old debate on the consequences of laws being implemented from one place to another [1]. Changes due to development occur rapidly, especially in the field of information and communication [2]. The fourth industrial revolution, also known as Industry 4.0, is marked by artificial intelligence, supercomputers, genetic engineering, nanotechnology, autonomous cars, and innovation. These changes occur exponentially, impacting economies, industries, governments, politics, and laws. In this era, the shape of the world is increasingly seen as a global village. Based on the Mckinsey Global Institute analysis, Industry 4.0 has a tremendous and broad impact, especially in the labor sector. In this era, robots and machines will eliminate many occupations [3].

New problems have emerged for human resources in Industry 4.0 as this era requires reliable, superior, and specialized human resources. In the legal profession, a position such as a notary is required to improve their services to the community by maximizing existing information technology. In Industry 4.0, notaries must have critical thinking skills, solve problems, communicate, create, and collaborate.

It is common to classify the existing legal systems into three prominent legal families or traditions, namely civil law, common law, and socialist law [4]. The notarial profession operates 
globally on two legal systems: a Notary in a nation of laws and a Common Law Notary commonly referred to as a Public Notary. Although both are notaries, they differ in functions and authority. Indonesia adheres to a civil law system that uses written laws or regulations as its primary source of law [5]. Notaries act as a trusted third party to bridge cooperation contracts/agreements in electronic transactions, which will more frequently utilize cybernotaries. The influence of technology on the activities of notaries disturbs the existing status quo; computer-literate notaries will make appropriate changes and welcome the assistance of technology, while those who are not will choose to stick to current procedures.

However, there has been no specific regulation to date in Indonesia regarding the mechanism for deed creation using electronic media, which incidentally is a branch of the cybernotary system [6]. The cybernotary is intended to facilitate and accelerate the process of creating authentic deeds, including complying with all actions, agreements, or provisions required by law and ensuring all requested statements from interested parties are stated in the authentic deed. Creating a notarial deed through online methods is expected to facilitate involved parties. However, the use of online technology is faced with legal problems [7].

The implementation of the cybernotary is a form of adjustment to the needs of society and the times. It can also support cybersecurity and resilience in Indonesia, which require strong, professional, and reliable institutional support to ensure that the objectives of cyber defense can be achieved.

\section{Cybernotary in Achieving Defense and Security}

\subsection{Cybernotary Concept in Indonesian Positive Law}

In line with the launch of Industry 4.0, digital technology has become the choice for most people to carry out almost all activities, including domestic and cross-border commercial transactions. This shift in transactional behavior has changed the form of contracts or agreements made by the public in their daily activities; electronic contracts have become the norm for electronic transactions. To anticipate this new phenomenon, the Indonesian government has issued a series of regulations that regulate and provide legal and implementational certainty and the legality of electronic transactions, including electronic contracts, following Government Regulation Number 82 of 2012 concerning Electronic Systems and Transaction Implementation.

In Europe and America, cybernotary operations using digital signatures have been implemented since several years ago. European countries whose notaries have switched to digital signatures using public key technology are Spain and the UK, supported by relevant changes to their respective government regulations. In the United States, seven states have implemented digital signatures in notarial practice since 2007. Japan has utilized cybernotary for the past 15 years [8].

The term Cybernotary was first introduced by the American Bar Association (ABA) in 1994. This concept states that a person who carries out cybernotary activities is someone who possesses specialized skills in the field of law and computers. Furthermore, this concept perceives the function of a cybernotary to be analogous to Latin notaries. They can facilitate international transactions, electronically authenticate documents, and verify legal capacities and financial responsibilities [9]. 
The E-Notary concept proposed by France represents the perspective of civil law or Continental European legal system. In contrast, ABA's proposal on cybernotary represents a common law or Anglo-American system perspective. Thus, as a country that adheres to the civil law system, Indonesia is more suited to adopt E-Notary. However, the explanation of Section 15 Paragraph (3) of Notary Law explicitly states the term Cybernotary. Based on these facts, there are opinions stating that Indonesia should not adopt the concept of Cybernotary as it is and suggest its reconceptualization to better suit Indonesia.

The birth of technology has resulted in convergence (integration) in technology, communication, media, and information (telematics). At first, each of these technologies appeared to run separately (linearly) from one another, but now all of these technologies have become increasingly convergent. Telematic convergence is marked by the birth of new technology products that combine the capabilities of information and communication systems, are based on computer systems, and are strung together in one local, regional, or global electronic system network [10].

In the future, the legal prospects of cybernotary may be used as a means to support the activities of a notary. Activities carried out in the millennial era can be conducted using a conventional system. Notaries and relevant parties utilize the internet to create authentic deeds as written evidence regarding circumstances, events, or legal actions. The cybernotary is an idea born in the millennial era under current technological developments that require legal reform, as stated by Salim HS. In the book An Introduction to the Philosophy of Law (1954), Roscoe Pound states that law is a tool of social engineering or, in other words, a tool for community reform [11].

The development of information technology has greatly influenced people's lives, which prompted the government to issue Law of the Republic of Indonesia Number 19 of 2016 concerning Amendments to Law Number 11 of 2008 concerning Information and Electronic Transactions. The development of information technology has inevitably led every activity to shift and or move from conventional systems to electronic systems; notary services are no exception known as Cybernotary. A notary can use technology in carrying out notarial work such as e-notary or Cybernotary. However, some people question the validity of the deed made in the Cybernotary system. They argue that Cybernotary is contrary to the principle of the tabellionis officium fideliter exercebo, which means that a notary must work traditionally [12]. Therefore, a regulation should be made to improve the competence of notaries to utilize information technology systems. Considering the shift of such change is massive, all parties must implement e-notary, and the policy must be at the national level, not sectoral.

There are two main aspects of cybernotary, namely authority and technology. Progress in the economic sector has interconnected these two aspects. Rapid economic changes require notaries to process contracts immediately; one of the means to support the acceleration of this process is information technology. Apart from playing a role in contract creation, notaries are also authorized to validate signatures, store deeds, provide Grosse, copies, and excerpts of deeds, and keep documents underhand. In addition, the development of information technology has also greatly influenced lives and prompted the government to issue Law of the Republic of Indonesia Number 19 of 2016 concerning Amendments to Law Number 11 of 2008 concerning Electronic Information and Transactions.

Several terms are used to describe the use of technology by a notary in carrying out their work, such as e-notary and cybernotary. In Indonesia, the concept often uses the term cybernotary. This concept raises various opinions, both in favor of and against. The main problem that arises is the validity of deeds made using cybernotary. Some argue that cybernotary 
contradicts the principle that has been held so far, namely the principle of tabellionis officium fideliter exercebo, which means that a notary must utilize traditional means [12].

The opportunity to implement cybernotary is widely open with the existence of supportive regulations. Several applicable laws and regulations, including Article 15 Paragraph (3) of Law Number 2 of 2014 concerning Amendments to Law Number 30 of 2004 concerning Notary Position, which states that in addition to the authority as referred to in Paragraph (1) and Paragraph (2), the Notary possesses other authorities regulated in the laws and regulations. As stated in the regulations on Electronic Information and Transactions, this includes the implementation of cybernotary. Notaries tend to agree that archiving will be much more efficient if done electronically rather than physically. Therefore, a regulatory basis that can improve the competence of notaries on information technology systems is needed. Considering the massive nature of the changes, the implementation of e-notary must be agreed upon by all parties, and the policies must be registered at the national level, not sectoral.

\subsection{Implementation of Cybernotary to Support the Cybersecurity and Resilience of Indonesia}

The Cybersecurity Strategy of Indonesia acts as a standard reference for all national cybersecurity stakeholders in compiling and developing cybersecurity policies in their respective agencies. It is developed in line with the basic values of the life of the people and nation, namely Sovereignty, Independence, Security, Togetherness, and Adaptiveness [13].

Legal developments create reliable ways to store and retrieve information. Two hundred years ago, there were no photocopiers or computers. The parol evidence rule dealt with the main problem of documentary evidence, namely the authenticity of contracts and deeds [14]. Many jurisdictions have arranged for the receipt of electronic evidence as legal proceedings. This issue has also been dealt with regionally, such as through Directive 1999/93/EC of the European Parliament and of the Council of 13 December 1999 on a Community framework for electronic signatures, which states that electronic signatures cannot be denied its effectiveness and legal acceptance as evidence in legal proceedings solely on an electronic basis. Likewise, Section 9 (1) of Directive 2000/31/EC of the European Parliament and of the Council of 8 June 2000 on certain legal aspects of information society services, in particular electronic commerce, in the Internal Market (Directive on electronic commerce) states that contracts will not lose effectiveness and legal validity if made using electronic means. It is generally accepted that evidence in electronic format is acceptable in legal proceedings [15].

Cybernotary is not simply digitalizing the duties of a notary but rather adding value to electronic documents, for example, legalizing electronic documents. However, its implementation will take considerable time as many things need to be prepared. One of them is the amendment to Section 1868 of the Civil Code, which states that authentic deeds are deeds in a particular form that has been determined by the law and made in the presence of public authorities.

The concept of cybernotary has always been associated with long-distance services, for example, remote deed making. According to Edmon Makarim, cybernotary is, in principle, not much different from regular notaries. The involved parties still meet face to face with the notary. However, the difference is that the parties read the draft on their respective computers and after agreeing, the parties electronically sign the deed at the notarial office. Making a deed does not have to be perceived solely in papers. Functionally a deed can be done electronically without denying the applicable rules and regulations. 
In the millennial era, notarial services are adapting computerized systems, which is a new phenomenon. R.A. Emma Nurita stated that the notarial world is a phenomenal world with various attributes and activities carried out by notaries daily, including providing the best service for their clients. By law, a notary is expected to help and serve those requiring authentic written evidence regarding circumstances, events, or legal actions. On this basis, those who are appointed as notaries must have a passion for serving the community. Therefore, a notary serves no purpose if the community does not require them [16]. This strengthens the role of Indonesian cybersecurity to strengthen defense and security, as the existence and involvement of the community greatly determine the importance of cybersecurity in Indonesia. The concept of Cybernotary is just the opposite. A physical meeting is not absolute, and it can be replaced by telecommunication technology through a virtual meeting. Virtual meeting in making a deed has ignited a legal debate to compare between a conventional notary deed and an electronic notary deed [17].

In order to properly carry out cybersecurity, robust, professional, and reliable institutional support is needed to ensure the goals to be achieved. This ensures that the foundations of Indonesia's cybersecurity and resilience can face various multidimensional threats/attacks, both from within and outside the country. The government and the People's Representative Council are drafting a bill on cybersecurity and resilience (CSR). It is hoped that governmental actions in the field of cybersecurity and resilience respect human rights.

Implementing the cybernotary concept is not just a common need but also protects notaries and strengthens the defense and security of the nation. In addition to explaining the best practices regarding e-notary in various countries, problems arising from conventional notarial methods can be prevented by implementing cybernotary. For example, a notarial deed document that uses paper can be faked, whereas if utilizing electronic media, the potential for forgery is slim to none. In fact, electronic documents have a more up-to-date recording system to prove forgeries easily. Functionally, all things done on paper can also be done in electronic documents, so its authenticity can be equated. This is supported by the functional equivalent approach doctrine used in the Electronic Information and Transactions Law.

\section{Conclusion}

Cybernotary is intended to facilitate and accelerate the process of creating authentic deeds, including complying with all actions, agreements, or provisions required by law and ensuring all requested statements from interested parties are stated in the authentic deed. The concept itself is open for implementation with the existence of several supportive applicable laws and regulations, including Article 15 Paragraph (3) of Law Number 2 of 2014 concerning Amendments to Law Number 30 of 2004 concerning Notary Position, which is hereinafter called Law on Notary Positional Change. To increase the competence of notaries on information technology systems, it is necessary to have appropriate regulations with the agreement of all related parties. In addition, these regulations must be registered at the national level, not sectoral.

The implementation of the cybernotary concept is not just a common need but also protects notaries. The Cybersecurity Strategy of Indonesia acts as a standard reference for all national cybersecurity stakeholders in compiling and developing cybersecurity policies in their respective agencies. It is hoped that the enforcement of government authority in cybersecurity and resilience respects human rights, as the concept of cybernotary is always associated with long-distance services. 


\section{Acknowledgment}

This research was completed with the participation and support of mentors and students of the Doctor of Law Science Program, Universitas Sumatera Utara.

\section{References}

[1] W. Menski, "Perbandingan hukum dalam konteks global sistem Eropa, Asia dan Afrika." Bandung: Nusa Media, 2016.

[2] T. H. Krisyanto, Z. Daulay, and B. Beatrix, "Strength of Evidence of Notarial Deed in the Perspective of Cyber Notary in Indonesia," Int. J. Multicult. Multireligious Underst., vol. 6, no. 3, pp. 775-784, 2019.

[3] H. Isnaini and W. Utomo, "The Existence of the Notary and Notarial Deeds within Private Procedural Law in the Industrial Revolution Era 4.0," Int. J. Innov. Creat. Chang., 2019.

[4] P. De Cruz, "Perbandingan Sistem Hukum, Common Law, Civil Law dan Socialist Law," Bandung. Nusa Media, 2010.

[5] M. Fuady, "Perbandingan Ilmu Hukum," 2007.

[6] T. Maharani, L. Parman, and L. M. H. Haq, "Cyber Notary System in the Order of Norms in Indonesia and Australia (Comparative Study in Notary Service Improvement Strategies)," Int. J. Sci. Res. Manag., vol. 7, no. 05, 2019.

[7] M. Ridwan, "Reconstruction Of Notary Position Authority and Implementation Of Basic Concepts Of Cyber Notary," J Akta, vol. 7, no. 1, 2020.

[8] B. Schotel, "Legislation, empirical research and juridical law," Theory Pract. Legis., vol. 1, no. 3, pp. 501-532, 2013.

[9] H. I. Prasetya, "Memaknai Implementasi Konsep Cyber Notary Dalam Pelaksanaan Lelang," Kementerian Keuangan, 2020. [Online]. Available: https://www.djkn.kemenkeu.go.id/artikel/baca/13397/Memaknai-Implementasi-Konsep-CyberNotary-Dalam-Pelaksanaan-Lelang.html.

[10] H. S. Salim, Perkembangan Teori Dalam Ilmu Hukum. Rajawali Pres, 2010.

[11] S. Syamsir and Y. Yetniwati, "Prospek Cyber Notary Sebagai Media Penyimpanan Pendukung Menuju Profesionalisme Notaris," Recital Rev., vol. 1, no. 2, pp. 132-146, 2019.

[12] A. W. Wijaya, "Konsep Dasar Cyber Notary : Keabsahan Akta dalam Bentuk Elektronik," vVva Justicia, 2018. [Online]. Available: https://vivajusticia.law.ugm.ac.id/2018/11/29/konsep-dasarcyber-notary-keabsahan-akta-dalam-bentuk-elektronik/.

[13] H. Siburian, "Pengantar Strategi Keamanan Siber Indonesia," Badan Siber dan Sandi Negara. [Online]. Available: https://bssn.go.id/strategi-keamanan-siber-nasional.

[14] R. J. Allen, T. Fry, J. Notebaert, and J. VanDam, "Reforming the Law of Evidence of Tanzania (Part Two): Conceptual Overview and Practical Steps," BU Int'l LJ, vol. 32, p. 1, 2014.

[15] S. Mason and U. Rasmussen, "The Use of Electronic Evidence in Civil and Administrative Law Proceedings and Its Effect on the Rules of Evidence and Modes of Proof," Strasbourg, 27 July, 2016.

[16] E. Nurita and R. Ayu, Cyber notary: pemahaman awal dalam konsep pemikiran. Refika Aditama, 2012.

[17] E. Makarim, "Notaris dan transaksi elektronik: kajian hukum tentang cybernotary atau electronic notary," 2020. 